\title{
The inclusiveness of mixed ability grouping in Johannesburg primary schools
}

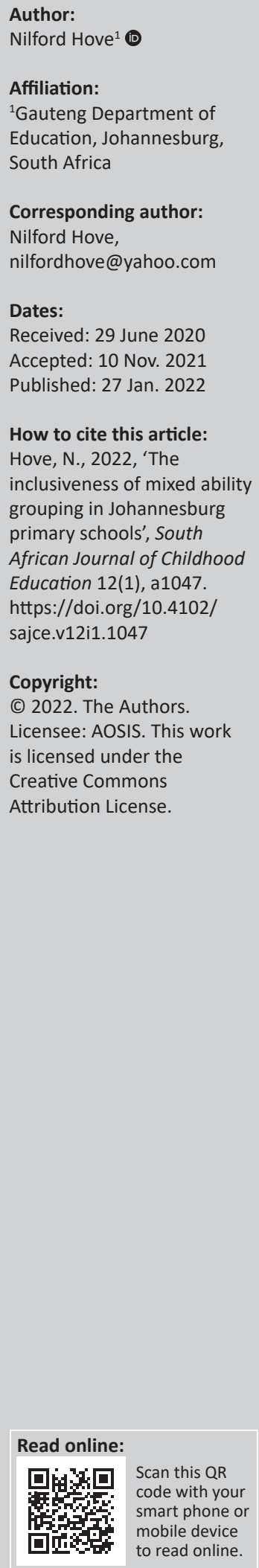

Background: South Africa adopted the policy on inclusive education in 2001 that aimed at offering quality and equity in education to all learners, as well as addressing their diverse needs in the classrooms despite their differences. Mixed ability grouping is one of the commonly used classroom practices in the schools, but little is known on how it reflects on principles of inclusivity.

Aim: The study aimed to explore how mixed ability grouping reflects on inclusivity as one of the commonly used classroom practices.

Setting: This qualitative study embedded in descriptive phenomenology was carried out in six selected primary schools of Johannesburg's Metropolitan region of South Africa.

Methods: Six participants and their classrooms were purposefully sampled, and data were collected through observations and in-depth interviews with each individual participant. Data were analysed thematically and the organisation of the emerging themes was informed by Florian and Black-Hawkins' model on inclusive pedagogy.

Results: Findings of this study revealed that mixed ability grouping takes into account learners' levels of academic performance, gender parity, age of learners, as well as learners' backgrounds leading to diverse learners accepting one another in the classrooms. However, there are challenges in providing differentiated instruction, using appropriate teaching/learning media, and opportunities for individualised instruction according to learner needs.

Conclusion: The study argues that for mixed ability grouping to be more inclusive, it has to provide for differentiated instruction within the same group setups, use teaching/learning media that are tailored to meet specific needs of individual learners, as well as offering individual instruction to learners who need it.

Keywords: grouping practices; mixed ability grouping; inclusive education; regular classes; differentiated instruction; cooperative learning, social skills.

\section{Inclusive education}

South African classrooms generally accommodate learners who are diverse in terms of age, socio-economic statuses, historical background, gender, sexual preference, ability and interests, amongst other differences (Van Vuuren, Van der Westhuizen \& Van der Walt 2016). This has sparked immense interest on how classroom pedagogic practices are capable of addressing the needs of diverse learners in the regular classrooms in light of policy on inclusion.

Inclusive education is grounded in the need to respect learner differences without compromising quality education for others based on prejudices stemming from what makes them different (Florian 2015). South Africa as a signatory to world conventions on inclusive education like UNESCO (1994) adopted Education White Paper 6 in 2001 to serve as a guide to the implementation of inclusive education in the country. Fundamentally, the South African Education White Paper 6 (2001), firmly states that: (1) needs of all learners must be met in the classrooms; (2) differences in learners should be respected; and (3) attitudes and teaching methods must change to meet the needs of all learners (DoE 2001). Attaining these goals requires classroom pedagogical shifts from approaches that deliberately target learners with 'additional needs' to learning for all (Florian \& Black-Hawkins 2011).

Modern-day studies reveal different grouping patterns as classroom pedagogic approaches that are practised internationally which include ability grouping (Ramberg 2014), mixed ability 
grouping (Petrenas, Puigdellivol \& Campdepadros 2013) and pairing (Jalali-Moghadam \& Hedman 2016). In this article, I specifically focus on the inclusiveness of mixed ability grouping as one of the widely used learner centred classroom pedagogies.

\section{Mixed ability grouping}

Traditionally, mixed ability grouping has been understood to entail having learners of different academic abilities placed in one group, so that they can learn together, honing specific subject knowledge as well as developing the intrapersonal and interpersonal skills and attitudes that are necessary in their daily activities (Wiesen 2013). Advocates of inclusive education believe that mixed ability grouping is an effective way to assimilate leaners with disabilities with their counterparts without disabilities, as they can engage one another in the learning processes (Hallahan, Kauffman \& Pullen 2011). There are specific benefits that learners can tap from mixed ability grouping such as affording lower functioning learners access to models. Ceri (2013) argued that mixed ability grouping is the most successful grouping practice for a child's learning because learners of different levels of intelligence, interests and backgrounds can interact and learn with each other. Learners with articulation problems can benefit from hearing the more appropriate of their peers express themselves, leading to the improvement of social relations amongst different learners (Kruger \& Nel 2011; Vaughn, Bos \& Schumm 2011).

A contemporary study by Al-Shammakhi and Al-Humaidi (2015) in Oman revealed that mixed ability groups enable learners with special educational needs to learn important social skills from their peers without disabilities through imitation from within the same groups. Social skills they learn from their peers without disabilities include problemsolving skills, respect for one another and talking to each other in polite ways amongst others. Mixed ability grouping in Finland is influenced by the argument that the idea of ability grouping perpetuates exclusion of some learners as those placed in low ability groups are predisposed to achieving lower educational outcomes and therefore channelled towards doing low challenging work than their counterparts in the same classrooms (Al-Shammakhi \& Al-Humaidi 2015).

Mixed ability grouping in New Zealand goes beyond mere abilities of learners as ethnically diverse domestic learners and predominantly Asian international learners learn in mixed ability settings to erase the social differences created by their differences in backgrounds and ethnicity (Baker \& Clark 2017). Pohtola (2015) reported that teachers in Sweden assign learners to different groups rather than letting learners decide where they want to sit in their classrooms (Pohtola 2015). This is done to minimise playfulness amongst learners who are friends if they sit in the same group as well as to ensure that every learner is accommodated in mixed group settings.
A qualitative study by Naude and Meier (2019) in the Tshwane District of Gauteng in South Africa revealed the use of mixed ability groups in the classrooms where learners with disabilities are supported by their peers without disabilities. A similar study by Bojuwoye et al. (2014) established that in the Eastern Cape province of South Africa, learners who are underperforming in primary schools are mixed with learners who are performing well so that they can be assisted by average and gifted learners.

Despite the benefits of mixed ability grouping, convolutions in differentiating instruction, giving more assistance to learners with special educational needs, and providing teaching/learning media that address the needs of all learners have been distinguishable elsewhere. For example, a study by Petrenas et al. (2013) on ways to organise the inclusive classroom depicted difficulties in curriculum differentiation as teachers cease to give attention to some learners when they are in mixed ability groups because they cannot attend to everyone in the groups. Regular class teachers' lack of training in curriculum differentiation (Bubpha 2014), as well as huge learner populations in the classrooms inadvertently lead teachers towards channelling learners into categories based on the amount of support an individual leaner requires, (Bubpha 2014; Duncan 2012). The above is supported by Saaris (2021) who argued that meeting the individual needs of diverse learners is challenging when learners are in mixed ability groups and this is driving some schools to rethink the benefits of mixed ability groups in light of policy on inclusion.

In some instances, teaching learners in mixed ability groups lead teachers to spending more time explaining to the weaker learners, culminating in academically stronger learners getting bored because they feel they are being excluded in the learning processes (Walters 2017). In addition, some parents get concerned that their high achieving child will be held back by less intelligent classmates (Walters 2017). A further argument raised against mixed ability grouping in light of policy on inclusivity is that gifted learners are forced to work at the slower pace that learners with special educational needs require as they will be expected to learn and progress at approximately the same rate despite differences in their abilities. In that light, Marumo and Mhlolo (2017) argued that mixed ability grouping does not benefit learners who are gifted because they are being held back by underperforming learners thereby depriving them of opportunities to unlock their potentials through more exploratory methods of learning.

Inclusive education requires the use of teaching/learning materials that address the unique needs of individual learners in the classrooms but within the same group settings (Florian \& Black-Hawkins 2011). This is a challenge that teachers face in the classrooms given the learner diversity in mixed ability groups as they encounter challenges in providing teaching/ learning materials for the various categories of learners in the same groups, impinging on one of the principles of inclusion 
which requires the provision of teaching/learning materials that are appropriate to the needs of each individual learner (Tanenbaum 2011).

\section{Aim of the study}

This study was aimed at exploring the inclusiveness of mixed ability grouping in the regular classrooms, based on the inclusive education requirement to teach all learners in the same settings regardless of their categorical differences. The policy of inclusive education enunciates that all learners should access quality education in the same environments in spite of their diversity. In line with the policy of inclusivity, the study sought to answer to the question: How inclusive is mixed ability grouping in the regular classrooms?

\section{Theoretical framework}

The study was carried out through the lens of Florian and Black-Hawkins (2011)'s theory of inclusive pedagogy that was framed out of the need to define what constitutes good practice in the regular classes in light of the inclusive education movement. Fundamentally, inclusive pedagogy emphasises a change in teaching and learning from that which works for some learners towards that which involves learning opportunities that suit all learners and provide a rich learning community for all (Florian \& Black-Hawkins 2011). Teachers who want to become more inclusive in the classrooms respect and respond to their learners' differences and are able to include learners rather than excluding them from what is generally available in their classrooms. In light of the above, learners need to be grouped in ways that embrace diversity and, at the same time, are able to give support to learners who need it; ensure improvement in learners' academic attainment without excluding anyone from any group setup and give optimum support to all learners. Inclusive pedagogy emphasises three broad aspects which are: (1) that education in regular classes should focus on all learners and not some or most; (2) the presence of some learners in the classrooms should not hold back the progress of others and (3) difficulties in learning should be seen as a professional challenge for teachers and not deficits in learners. This theory was chosen because it defines how inclusive education should be viewed in practice at a classroom level. Gauging against its three broad principles highlighted above, I envisaged that I would be able to explore the inclusiveness of mixed ability grouping in the Johannesburg Metropolitan region regular classrooms.

\section{Method}

A qualitative research method was used through descriptive phenomenology design which allows for flexibility to study the topic deeper and to extract the most information possible to explain the details on how mixed ability grouping reflects on inclusivity. I chose descriptive phenomenological design because it enables participants to explain their lived experiences through their individual voices (Williams 2012). I needed to extract more detail from the participants about their different experiences and perceptions about the inclusiveness of mixed ability grouping through observations and in-depth individual interviews as data collection tools. Phenomenological research design involves getting each participant to focus on his or her phenomenological space and to describe their experiences in their own terms (Bordens \& Abbott 2011).

\section{Participants and setting}

A total of six regular class teachers and their classrooms were purposefully sampled as participants and study sites, respectively. Purposeful sampling enabled me to select information-rich cases to give detailed information about phenomena under study (Arthur et al. 2012). Participants who had qualifications in inclusive education and experience in teaching in regular classes in South African regular primary schools were selected. Set criteria were used to determine the appropriateness of an individual to take part in the study. The criteria that were used in selecting the sample contained the following: 1) an understanding of South African policies on inclusive education; 2) qualification in inclusive education; 3) 5 years teaching experience in the regular classrooms and 4) 5 years experience in teaching learners with special educational needs.

All the sampled schools were located in the high density townships of the Johannesburg Metropolitan region of South Africa that enrol learners who are widely diverse in ability, ethnicity, linguistic backgrounds, gender, age and religion, amongst other differences, in line with the dictates of DoE (2001), which stipulates that all children should be accommodated in schools nearest to them. The Johannesburg region has five districts in terms of delimitations by the Gauteng Department of Education, which are: Johannesburg Central, Johannesburg East, Johannesburg North, Johannesburg South, and Johannesburg West.

\section{Data collection}

Observations and in-depth interviews were used in the collection of data. Interviews lead to face-to-face engagements with research participants individually that are not possible with questionnaires or focus groups (Atkins \& Wallace 2012). Researchers can make follow-up questions on initial responses by probing for additional information that can clarify existing data (Savin-Baden \& Major 2013). Observations were also used in this study which enabled me to understand behaviour as it occurs without external constraints and control (McMillan \& Schumacher 2012).

\section{Data analysis}

Thematic analysis approach was used, using a model by Lodico, Spaulding and Voegtle (2010). This involved gradually collecting numerous small pieces of collected data to form broader, more general descriptions and conclusions. I took notes from both observations and interviews which were later transcribed for meaning and depth. I went through the process of expanding field notes from observations that were written in shorthand to give detailed descriptions of the perceptions of the participants on the phenomenon under study as well as 
transcribing interview recordings. Data coding involved identifying different segments of the data that described related aspects of the study and gave them broad names. The idea was to put related data together for easy interpretation and discussion. The coding of data was followed by the construction of thick descriptions of both participants and the schools that were visited for the purposes of data collection, after which themes were identified in the study.

\section{Ethical considerations}

McMillan and Schumacher (2010) argued that observationbased research requires that we pay particular attention to the ethical aspects of our projects. Participation in the research, both in observations and interviews, was voluntary. I took steps which included: (1) avoiding harming research participants; (2) obtaining informed consent and (3) maintaining privacy and confidentiality, in order to avoid contestations that might arise because of the avoidance of ethical issues (Check \& Schutt 2012). I gave participants a full description of the research aim and told them of their right to decide not to participate through a consent form which explained what it meant to be involved in the study and the purpose of the research. I assured participants that what they said would not be traced back to them as their names would only be known to me. Maintaining privacy and confidentiality during and after a study is a way to protect subjects (Check \& Schutt 2012). I carried out the research overtly, with participants well aware of all the necessary information about the study. I tried to be as honest as possible in the transcribing of the recorded data so that it was a true reflection of what the participants had said.

\section{Results and discussion}

Two themes emerged from this study which were; 1) Inclusiveness of mixed ability grouping, and, 2) Challenges with mixed ability grouping.

\section{Theme 1}

\section{Inclusiveness of mixed ability grouping}

The study findings revealed that mixed ability grouping takes into consideration learners' levels of academic performance, gender parity, age of learners and learners' backgrounds when constructing the groups in the classrooms. Ultimately, the above considerations lead to learners who are diverse accepting one another in the classrooms.

\section{Learners' levels of academic performance}

Mixed ability groups enable learners of different academic achievement levels to learn together collaboratively in the same groups. Observations at three primary schools in Johannesburg West, Johannesburg South and Johannesburg Central witnessed different learners encouraging each other to express their views on the questions asked in different tasks that had been given to them. Brighter learners were encouraged by their teachers to assist learners who were struggling within the groups. In one group at one of the schools in above-mentioned regions, learners were seen giving each other opportunities to give their answers in a rotational manner, with no omissions of any learner. Other group members elaborated on behalf of learners who were not fluent in English when they worked on 'shapes' in a mathematics lesson.

Interview responses from participants were that learners of different abilities can learn from one another when they are in mixed ability groups. Those with communication challenges can learn from their peers without disabilities if they are allowed to learn collaboratively. This includes basic language skills such as how to express themselves, articulate themselves, argue a point out and reading. They can also improve their writing skills as well as analytical skills and comprehension as expressed by participant 3 below (who is a male 47 year old teacher with 19 years experience teaching in regular classrooms. He holds a Certificate in Education as well as a Bachelor of Education Degree in Special Needs):

'Learners having challenges in language, learn from others how to speak ... how to read certain words, how to argue certain issues when they are in mixed ability groups. By so doing, they end up actually trying to demonstrate what they would have learnt from their peers. Academically, the learners learn to improve their writing skills, their analytical skills, comprehension generally improves. Also, they improve in articulating certain points and their general performance improves.'

Another participant, participant 6, (a 46 years old female teacher with 21 years teaching experience, and has a certificate in Education and a Diploma in Special Needs Education), stressed the importance of enabling learners with disabilities to interact with learners without disabilities in the group rather than solely relying on the teacher when she indicated that:

'Instead of me being the teacher talking to them and they are responding, they also need that time where they learn from one another. There are some learners who don't even like participating when it's the whole class, but when it is group work, they will be forced to participate.'

The above findings indicate that mixed ability grouping offers diverse learners the opportunity to learn together with others who are different from them in terms of ability, enabling them to improve on their communication skills and their general academic performance despite their differences. Many learners with special educational needs face challenges in holding a conversation, expressing their feelings, participating in group activities and responding to failure or criticism in constructive ways (Heward 2014). These challenges can be erased if diverse learners have optimum opportunities to interact amongst themselves. Inclusive pedagogy is of the view that such learners should be able to learn with others in the classrooms (Florian \& Black-Hawkins 2011). Smith et al. (2011) posited that placing a learner in an inclusive classroom does not guarantee social acceptance or inclusion. For a learner with disabilities to 'fit' in the larger groups, he and/or she 
has to participate in ongoing social play and be able to continue to interact (Deiner 2013). When learners are in mixed ability groups, they are more readily approachable and they lend support in a more natural and informal way (Pienaar \& Raymond 2013). Heward (2014) viewed this as the 'buddy system' in which partners serve as positive role models in social interactions, and provide the support their partners need to be included within general education.

\section{Gender parity}

Besides the academic achievement levels of learners, gender of learners is also considered when learners are grouped according to mixed ability in the regular classrooms. Observations at four schools noted learners who were mixed in terms of gender in all the groups where both boys and girls were seen working together collaboratively on different tasks in the same mixed ability groups. In one of the classes, there were equal numbers of boys and girls in each group, except in one group where there were five boys and three girls because there were more boys than girls in that class. Three participants confirmed the infusion of gender of learners with their levels of abilities when grouping them in mixed ability groups as stated by participant 1, (a 40 years old female educator with 19 years teaching experience, and has a B Ed degree in Special Needs Education), who was captured saying:

\footnotetext{
“'We don't only consider performance, but marks oriented with gender. A boy who is struggling should also be in a group where there are boys and girls who are doing well. The same with girls who are having challenges in map work. They should have that inclusiveness that everyone is accommodated. So basically, when it comes to the aspect of gender, learners who are females should be comfortable to sit next to learners who are males." Ms. Mzila corroborated the above when she stated that: "I try to combine girls and boys but mixing them in their performances. For example, boys who are not doing well in 3-d shapes can be in a group of girls who are doing well in 3-d shapes. The same with girls, they have to be used to each other irrespective of their gender."'
}

The above finding indicates that gender of learners is considered when grouping learners by mixed ability as teachers take measures to ensure that groups have both boys and girls in them. Considering the gender of learners when grouping them in the regular classrooms allows boys and girls to learn along side with each other and preserves their dignity in the classrooms (UNESCO 2005). The manifestation that mixed ability grouping accedes to the need for gender infusion in groups positively identifies with the principle of inclusivity - that of social justice for every learner (Tanenbaum 2011). The ideals of social justice can be viewed as the complete and equal participation of all learners in an environment that is mutually designed to meet all learners' needs (Geldenhuys \& Wevers 2013). Inclusive management should take into account education that allows all learners to learn together, to be recognised and to be provided with equal educational opportunities (Bubpha 2014). UNESCO (2005) averred that special efforts should be made to encourage the participation of girls in educational programmes and not to exclude them because of what they are (UNESCO 1994). The absence of learners of a particular gender from a group set-up is tantamount to discrimination and exclusion, which is against the dictates of inclusive pedagogy that stipulates that regular education has to be the most effective means for combating discriminatory attitudes, creating welcoming environments, and building an inclusive society (Mahlo 2013).

\section{Age of learners}

Besides gender parity in mixed ability groups, learners of different ages are accommodated in the same groups, as established through observations in five classrooms in five different schools. Older learners were seen learning together in the same groups with much younger learners. Three participants confirmed the consideration of age when they indicated that they group their learners according to mixed ability, but they also consider the ages of their learners in fairly distributing them to different groups. One of the participant 4, (38 years old female educator with 10 years teaching experience in the regular classrooms who holds Bed Degree and a Diploma in Inclusive EDucation), indicated that there are some learners who were retained in the same grade because they did not pass that grade the previous year and they were not progressed to the next grade. Such learners would be older than others in their current grade but they are accommodated in the same mixed groups as well. He was captured saying:

'If you check in grade six, you will be having learners who would have been retained in the same grade who are now older. They need to be accommodated so that they can feel they are part of the class ... In order to balance, you make sure that those learners are spread out in different groups. They should not be in one group because they will feel like marginalised.'

In the same vein, another participant, participant 1 stated that:

'If you put learners that were retained in one group, sometimes it can pull them down because the class can label them, can give them names that this is a group of old people in the class. So it's wiser to mix them so that they don't feel bad.'

Age of learners is factored in when grouping learners by mixed ability, as learners who are older for their grade levels are present in the regular classrooms as a result of being retained in the same grade because of poor attainment results the previous year(s). Inadvertently, such learners could be at risk of social rejection from their more abled peers without disabilities because they are older than most of the learners in the same classrooms. Inclusive education dictates that every learner must have a place and must be welcome in the regular classes, irrespective of their ages amongst other differences (Smith et al. 2011). Considering ages of learners when grouping them according to mixed abilities, it attests to the dictates of inclusive pedagogy, by incorporating all learners in one learning environment despite their differences (Florian \& Black-Hawkins 2011).

\section{Learners' backgrounds}

All the six classrooms visited revealed that there were learners of different backgrounds who were accommodated in same mixed ability groups as evidenced by the languages 
learners spoke in their various groups, besides the language of teaching and learning. Learners spoke in Sotho, IsiZulu, Xhosa, Sepedi, Venda, Tsonga and Tswana, amongst other languages, which indicated their diversity. In a life orientation class in one of the schools in Johannesburg West, the educator allowed learners to participate in group work using their mother languages. Some of the learners were reluctant to speak in English but were more comfortable when they used their mother language. At one school, one group of learners was not eager to share the learning experience with a learner who spoke Chichewa. A similar experience was noted at another one where a learner who spoke Venda was in a group of learners who were predominantly Sotho. Three participants noted that they ensured that learners from different backgrounds learn together in the same mixed ability groups, as asserted by one participant who indicated that the groups learners from different backgrounds in the same groups, allows learners who speak the same language to assist each other in the language that they understand better. Participant 2, (46 year old female educator with a Bachelor of Education Degree as well as an Honors Degree in Inclusive Education), explained that:

'When we use mixed ability, we don't want learners to be isolated or labelled because of who they are. So we make sure different learners are grouped together in one group. Most of the learners are coming from the townships, and they speak different languages. We allow them to use vernacular, those who can speak the same language in the groups, I give them the opportunity to interact in the groups using the languages they understand. Learners should be able to help one another within the groups regardless of who or what they are.'

Participant 3 stated that she takes learner diversity into account when she is grouping learners according to their mixed abilities. She was captured saying:

'What I always try to avoid is to expose learners who are minority in the class, like learners from other countries. So I put learners who are different in one group. They (learners) have to be able to cooperate and learn together, as they are all my learners, and I want them to feel that they are all the same.'

UNESCO (2001) postulated that learners' backgrounds must be taken into account in order to include all leaners in the education programmes. Most teachers use mixed ability groups because they believe that everyone has something to give to the group (Pohtola 2015). Allowing learners from different backgrounds to learn together with other diverse learners as established in the findings position them to gradually fit into the existing systems in the classrooms. It is not only the learners' abilities that should be the sole determinant factor in grouping learners in the classrooms, but also factors such as socio-economic status, ethnicity, gender and special educational needs (Ramberg 2014). Consequently, learners from diverse backgrounds must be in a group where at least one or more learners in the group is/are able to impose structure on the group (Reid 2012).

\section{Learner acceptance}

Findings also indicated that learners' levels of acceptance of their diverse counterparts are higher when they are in mixed ability groups. Observations established that learners with disabilities can develop friendships with other learners whom they are grouped with. At two schools, learners were seen sharing their mathematical instruments, textbooks, rulers, erasers and other teaching/ learning materials. Learners assisted each other with measurements to construct rectangles, pentagons and hexagons accurately. Those who finished their work first assisted other learners in drawing the shapes and in measuring the sides of the shapes. Two participants noted that mixed ability grouping promotes acceptance of one another as well as development and strengthening of friendships amongst learners as was noted by participant 5 (46 years old male educator with a Certificate in Education, a Diploma in Special Needs Education, as well as 23 years experience teaching in regular classrooms):

'They will look themselves as equal. You can see by sharing, they want to share and even if one learner takes out a book, the other one will not take the book, they will want to go and read together. That's one simple thing that can show that learners with disabilities are accepted.'

From the findings, social acceptance amongst learners with and without special educational needs is optimised when they are in mixed ability groups in the regular classrooms. This serves as the foundation on which lifelong patterns of social behaviour are constructed (Recchia \& Lee 2013). Such lifelong patterns prepare learners for societal acceptance because they learn to conform to the norms of the society through interaction with other learners who are different to them in the groups in terms of ability. Enabling diverse learners to interact socially amongst themselves gives them the opportunity to understand other learners, respect them, as well as to cultivate tolerance amongst different learners (Eredics 2015). Classrooms should provide a humane and caring society, not for the few, but for all learners as embodied in the values of human dignity and the achievement of equality (DoE 2001). A learner who is continually rejected may experience self-concept problems or general unhappiness and is likely to drop out of school (Bender 2008). Accordingly, enabling diverse learners to be in mixed ability groups promotes social acceptance of learners by the way they are, and not by what they can or cannot do (Florian \& Black-Hawkins 2011).

\section{Theme 2}

\section{Challenges with mixed ability grouping}

Findings revealed challenges in mixed ability grouping relating to difficulties in differentiating instruction, promoting the use of teaching/learning media and opportunities for individual teacher assistance.

\section{Differentiating instruction}

Observations carried out in all the classes visited revealed that teaching was done in a generic manner in the classes 
without differentiating instruction according to the needs of individual learners. Learners were being given the same written activities, both in quantity and in complexity. No specific instructions were noted being given to certain learners to carry out their tasks differently. Three participants noted that differentiation of instruction is difficult to implement when learners are in mixed ability groups as stated by participant 4 below who was captured saying:

'I cannot separate to say, uh, wena Siyabonga, you are doing this question, Sibonginkosi and others you are doing these questions, because I want them to feel that they are one. So I give them same questions in the whole group.'

Another participant, participant 5 indicated that he finds it difficult to use different methods of instruction for learners in mixed groups as he ends up giving them the same work despite their different levels of ability. He was captured saying:

'I give them the same work which they do as a group. It will be so challenging to give specific methods for different learners in a specific group.'

Teachers face challenges in differentiating instruction when learners are in mixed ability groups. Work is not differentiated according to the needs of the learners because teachers want them to feel that they are equal in the groups. Disadvantages of mixed ability grouping were noted in the generic approach to teaching and learning that is contiguous with the practice. Teachers find it difficult to differentiate instruction despite evident disparities in learner diversity within mixed ability groups because they want all learners to proceed at the same pace. Once learners are grouped by mixed ability, teachers cease to give attention to some learners in the groups because they cannot attend to everyone, which impacts negatively on the academic inclusion of learners who need more support from the teacher, (Petrenas et al. 2013). In cases where teachers try to give differentiated instruction to some individual learners in the groups, this poses the challenge of channelling learners into categories based on the amount of support an individual learner requires (Duncan 2012). In the same light, Marumo and Mhlolo (2017) averred that the progress of gifted learners is held back by underperforming learners if they are all in the same ability groups because teachers find it difficult to differentiate instruction.

\section{The use of teaching/learning media}

Findings established that mixed ability grouping inhibits teachers from using teaching/learning media that address the needs of specific learners based on their levels of ability. Teachers are resorting to the generic approach to teaching and learning without the use of teaching/learning media that are tailored to the specific needs of individual learners. Observations that were undertaken in all the classes did not reveal the use of teaching/learning media that specifically targeted certain learners. Interviews with individual participants revealed difficulties in using teaching/learning media when learners are in mixed ability groups as was stated by participant 3 who indicated that in mathematics, one cannot use learning materials that suit the levels of learners with disabilities if they are in mixed ability groups. He stated that:

'I can't use counters for challenged learners so that they can touch and see because this will disturb other learners in the group. Maybe their problem is they haven't mastered the concrete concepts at the concrete stage, so I would need to use the learning materials, which suits them but I can't. Those with disabilities, when you give them tough concepts, and also using the advanced learning materials, they don't participate very well. So they will be losing out ....'

Participant 5 indicated that she can't use different teaching/ learning media when learners are in mixed ability groups because of learners' different levels of operation. She argued that:

'Since they will be working as a group, you can't have one fraction chart for all learners as they are operating at different levels. Some they don't need the chart, and some benefit from that chart. So it's difficult to assist those who are struggling in the mixed ability groups.'

The above findings indicate that the mixed ability grouping obstructs learners with disabilities from learning through the use of different teaching/learning media that address their unique needs. Teaching/learning media can increase, maintain or improve functional capabilities of learners with special educational needs (Vaughn et al. 2011). In the same light, the use of any teaching/learning media in the regular classroom should be based on learner needs (Vaughn et al. 2011). For example, visually representing the elements of a narrative story with graphic organisers can help learners with learning difficulties to improve their comprehension (Heward 2014). Non provision of teaching/learning media does not reflect well with one of the principles of inclusive education which calls for the need to avail such media to learners with disabilities in order to maximise learning. In inclusive pedagogy, rich environments should be created within the learning centres for learners of different abilities to learn through manipulation (DoE 2014). Such arrangements maximise the participation of all learners within the same groups (Bubpha 2014). Furthermore, the provision of teaching/ learning media should be extended from what is ordinarily available to all learners in the class, rather than making 'different' or 'additional' provision for some individuals who might be experiencing difficulties in their learning (Florian \& Black-Hawkins 2011).

\section{Opportunities for individual teacher assistance}

Mixed ability grouping also deters learners with disabilities to receive individualised assistance from the teacher. Observations undertaken in all the classes revealed that teaching and learning go at a pace usually determined by fast learners, with no opportunity for the teacher to give individual assistance to those who are struggling. Interviews 
with all six participants who practised mixed ability grouping established that they are unable to give more assistance to learners with disabilities if they are in mixed ability groups. One participant, participant 3 was captured saying:

'It's difficult to concentrate a lot on the low achievers only because these ones will be needing your attention too. I attend to them as a group, when I find out that they are struggling, say with addition, I usually ask other learners to help them. As an educator, you don't get sort of enough time of interacting with them because the high achievers will be determining the pace at which we complete the topic or syllabus.'

Participant 4 noted that he faces challenges in using methods that suit the levels of operation of learners facing difficulties in mathematics when in mixed ability groups. He stated that:

'When learners are in groups, you use the same approach to teaching. Maybe someone is struggling but you have to teach him in the same way as another learner who is lacking. But the method he or she is teaching doesn't suit her ....'

The study established that teachers face challenges in giving extra support to learners in need when they are in mixed ability groups. Elsewhere Takala, Pirttimaa and Tormane (2009) established that teachers in Finland opt for one-on-one teaching because it offers focused attention to learners as opposed to mixed ability grouping. Teachers should be able to intervene in the groups by providing additional instruction as well as illustrations and examples to enhance learning (Frederickson \& Cline 2011), something that is not achievable in mixed ability groups. Teachers should be able to plan for specific groups/learners as well as increasing the intensity of interventions for learners with special educational needs (Vaughn et al. 2011), 'in ways that include learners, rather than excluding them, from what is ordinarily available in the daily classroom life' (Florian \& Black-Hawkins 2011).

\section{Recommendations and implications}

Research findings have indicated that mixed ability grouping is capable of promoting collaborative learning amongst different categories of learners, promoting social acceptance and the learning of social skills. Important aspects of inclusion are also considered which are: age of learners, gender and learners' backgrounds. However, teachers also need to consider using different grouping practices interchangeably, depending on the aspects of learning that need to be covered. Rigid adherence to one particular grouping practice can lead to the exclusion of learners in other aspects of learning. Successful inclusion involves restructuring classrooms to meet all learners' individual needs. Even though teachers treat their learners as equal for the purposes of social acceptance and inclusivity when they are in mixed ability groups, more effort has to be put for enabling differentiating of tasks in those groups. There is a need to balance between social inclusions and improving the levels of academic performance of all learners which should be provided within the grouping practices in the regular classes without necessarily separating learners.

\section{Limitations}

This study was carried out in six classrooms from the five districts of the Johannesburg Metropolitan Region in the Gauteng Province. Results only reflect the feelings and experiences of the teachers of those six classrooms, and do not allow for the generalisation of the findings on inclusiveness of the grouping practices to other districts within the regions of the Gauteng Province or the whole of South Africa. South Africa has a total of nine provinces. This implies that other regions might have different experiences and views on the grouping of learners in light of the policy on inclusion. Furthermore, the study was carried out in black township schools in the Johannesburg region. Other schools not in this category were left out of the study. As such, findings may not be representative of the other categories of schools that are not regular schools. The voices of practitioners in those schools were not heard, and teacher craft in those classrooms was not observed. To that end, the findings cannot be generalised to other settings.

The researcher is currently teaching in Johannesburg South District, one of the districts where the current study was carried out. It can be argued that any other person who is completely detached from the districts studied could have produced different results. In this current study, interviews and observations were the tools that were used to collect data and other methods of data collection, such as document analysis method, were excluded. This had the potential of limiting the study because the researcher only depended on two methods of data collection for the purposes of triangulation.

\section{Conclusion}

The study was aimed at establishing the inclusiveness of mixed ability grouping as one of the commonly used pedagogic practices in the classrooms. Teachers consider various factors such as age, gender, ability levels and learners' backgrounds when grouping. In addition, findings of the study indicated that mixed ability grouping promotes collaborative learning and learner acceptance amongst diverse learners. However, differentiation of instruction is difficult to give which impacts the progress of gifted learners within the groups.

\section{Acknowledgements}

The author would like to thank Prof N.T. Phasha for her guidance in article writing, as well as Ms. Shaw for her editorial input.

\section{Competing interests}

The author declares that there are no competing interests in as a result of this study. There are no financial or personal relationships that may have improperly influenced him in writing this article. 


\section{Author's contributions}

This article emerged from the author's doctor of education thesis that was supervised by N.T.P. Whilst the author received guidance from the author supervisor (N.T.P) on article writing, the actual writing of the article was done by the author himself.

\section{Funding information}

This research received no specific grant from any funding agency in the public, commercial or not-for-profit sectors.

\section{Data availability}

Data sharing is not applicable to this article as no new data were created or analysed in this article. Data from the author's Doctoral thesis were used in the writing of this article.

\section{Disclaimer}

Opinions and views expressed in this article are exclusively the author's own and all the sources used or quoted have been indicated by means of complete referencing.

\section{References}

Al-Shammakhi, F. \& Al-Humaidi, S., 2015, 'Challenges facing EFL teachers in mixed ability classes and strategies used to overcome them', World Journal of English Language 5(3), 33-45. https://doi.org/10.5430/wjel.v5n3p33

Arthur, J., Waring, M., Coe, R. \& Hedges, LV., 2012, Research methods and methodologies in education, Sage, Thousand Oaks, CA.

Atkins, L. \& Wallace, S., 2012, Qualitative research in education, Sage, Thousand Oaks, CA

Baker, T. \& Clark, J., 2017, 'Modifying status effects in diverse students groups in New Zealand tertiary institutions: Elizabeth Cohen's legacy for teacher education' Journal of Education for Teaching, International Research and Pedagogy 43(3), 338-348. https://doi.org/10.1080/02607476.2017.1321675

Bender, N.W., 2008, Learning disabilities: Characteristics, Identification and teaching strategies, Allyn and Bacon, Boston, MA.

Bojuwoye, O., Moletsane, M., Stofile, S., Moolla, N. \& Sylvester, F., 2014, 'Learners' experiences of learning support in selected Western Cape schools', South African Journal of Education 34(1), 1-15. https://doi.org/10.15700/201412121002

Bordens, K.S. \& Abbott, B.B., 2011, A process approach: Research design and methods, McGraw-Hill, New York, NY.

Bubpha, S., 2014, 'Models of inclusive education: One size does not fit all', Internationa Journal of Technology and Inclusive Education 3(2), 328-334. https://doi. org/10.20533/ijtie.2047.0533.2014.0042

Ceri, SA., 2013, Inclusive and ability grouping: The debate, viewed 28 February 2021, from https//ceristephenalexis.wordpress.com/part2-ability-groupingand-inclusion.

Check, J. \& Schutt, R.K., 2012, Research methods in education, Sage, Thousand Oaks, CA.

Deiner, L.P., 2013, Inclusive early childhood education development: Resources and practice, Cengage Learning, Wadsworth.

DoE, 2001, Education White Paper 6: Special needs education - Building an inclusive education and training system, Government Printers, Pretoria.

DoE, 2014, Policy on screening, identification, assessment and support, Government Printers, Pretoria.

Duncan, A., 2012, Matching students and instruction: The dilemma of grouping students, UCLA Center for Mental Health, Los Angeles, CA.

Eredics, N., 2015, 5 traits to look for in an inclusive classroom, Noodle, viewed 15 February 2021, from https://www.noodle.com.

Florian, L., 2015, 'Inclusive pedagogy: A transformative approach to individual differences but can it help reduce educational inequalities', Scottish Educational Review 47(1), 5-14.

Florian, L. \& Black-Hawkins, K., 2011, 'Exploring inclusive pedagogy', British Educational Research Journal 37(5), 813-828. https://doi.org/10.1080/01411926. 2010.501096

Frederickson, N. \& Cline, T., 2011, Special educational needs, inclusion and diversity, Bell and Bain, Glasgow.
Geldenhuys, J.L \& Wevers, N.E., 2013, 'Ecological aspects influencing the implementation of inclusive education in mainstream primary schools in the Eastern Cape, South Africa', South African Journal of Education 33(3), 18. https:// doi.org/10.15700/201503070804

Hallahan, D.P., Kauffman, J.M. \& Pullen, P.C., 2011, Exceptional learners: An introduction to special education. Pearson, Upper Saddle River, NJ.

Heward, L.W., 2014, Exceptional children: An introduction to special education, Pearson, Upper Saddle River, NJ.

Jalali-Moghadam, N. \& Hedman, C., 2016, 'Special education teachers' narratives on literary support for bilingual students with dyslexia in Swedish compulsory schools', Nordic Journal of Literacy Research 2, 1-18. https://doi.org/10.17585/ njlr.v2.224

Kruger, D. \& Nel, N., 2011, Addressing barriers to learning: A South African perspective, Van Schaik, Pretoria.

Lodico, G.M., Spaulding, T.D. \& Voegtle, K.H., 2010, Methods in educational research: From theory to practice, Jossey-Bass, San Francisco, CA.

Mahlo, D., 2013, 'Theory and practice divide in the implementation of inclusive education policy: Reflections through Freire and Brofenbrenner's lenses', Mediterranean Journal of Social Sciences 4(13), 163-170. https://doi.org/10.5901/ mjss.2013.v4n13p163

Marumo, J. \& Mhlolo, M., 2017, 'Grouping mathematically gifted learners: An analysis of teachers' practices in Free State High schools', Proceedings of the 23rd Annual National Congress of the Association for Mathematics Education of South Africa, Port Elizabeth, AMESA, 24 July 2017.

McMillan, J.H. \& Schumacher, S., 2010, Evidence-based inquiry, 7th edn., Pearson Upper Saddle River, NJ.

McMillan, J.H \& Schumacher, S., 2012, Research in education: Evidence-based inquiry, Pearson, Upper Saddle River, NJ.

Naude, N. \& Meier, C., 2019, 'Elements of the physical learning environment that impact on the teaching and learning in South African Grade 1 classrooms', South African Journal of Education 39(1), 1-11. https://doi.org/10.15700/saje. African Journal
v39n1a1342

Petrenas, C., Puigdellivol, R. \& Campdepadros, R., 2013, 'From educational segregation to transformative inclusion', International Review of Qualitative Research 6(2), 210-225. https://doi.org/10.1525/irqr.2013.6.2.210

Pienaar, C.F. \& Raymond, E.B., 2013, Making inclusive education work in classrooms, Pearson, Cape Town.

Pohtola, T., 2015, Differentiating instruction in EFL classrooms in secondary education, Fulbright Distinguished Awards in Teaching Program 2015-2016, Fulbright, Indiana, IN.

Ramberg, J., 2014, 'The extent of ability on grouping in Swedish upper secondary schools: A national survey', International Journal of Inclusive Education 20(7), 685-710. https://doi.org/10.1080/13603116.2014.929187

Recchia, S.L. \& Lee, Y.J., 2013, Inclusion in the early childhood classroom, Teachers College Press, New York, NY

Reid, G., 2012, Dyslexia, Continuum, London.

Saaris, N., 2021, How can students work together in a mixed classroom?, viewed 14 February 2021, from https://www.activelylearn.com/post/collaboration-mixedability-classroom.

Savin-Baden, M. \& Major, H.C., 2013, Qualitative research: The essential guide to theory and practice, Routledge, London.

Smith, E.C.T., Polloway, A.E., Patton, R.J. \& Dowdy, A.C., 2011, Teaching students with special needs in inclusive settings, Allyn and Bacon, Boston, MA.

Takala, M., Pirttimaa, R. \& Tormane, M., 2009, 'Inclusive special education: The role of special education teachers in Finland', British Educational Journal of Special Education 36(3), 162-172. https://doi.org/10.1111/j.1467-8578.2009. 00432.x

Tanenbaum, 2011, The seven principles for inclusive education, Center for Interreligious understanding, New York, NY.

UNESCO, 2001, Open file on Inclusive Education: Support materials for managers and adminstrators, Paris, UNESCO.

UNESCO, 1994, Salamanca statement and framework for action on special needs education, World Conference on Special Needs Education: Access and Quality, 7-10 June, UNESCO, Salamanca.

UNESCO, 2005, Guidelines for inclusion: Ensuring access to education for all, UNESCO, Paris.

Van Vuuren, H.J., Van der Westhuizen, C.P. \& Van der Walt, J.L., 2016, 'Leading and manage diverse schools in South Africa', Problems and Perspectives in Management 14(2), 240-249. https://doi.org/10.21511/ppm.14(2-1).2016.14

Vaughn, S., Bos, S.C. \& Schumm, S.J., 2011, Teaching students who are exceptional, diverse, and at risk in the general education classroom, 10th edn., Pearson, Upper Saddle River, NJ.

Walters, D., 2017, Mixed-ability classes: Factors, challenges and advantages, viewed 15 April 2020, from www.shaneschools.com.

Wiesen, N., 2013, Creating a culture of inclusiveness in the classroom. Cooperative learning strategies in the classroom, viewed 26 February 2020, from https://www. scilearn.com/blog/cooperative-learning-strategies-classroom.

Williams, K., 2012, 'A phenomenological study: African-American males in the educational profession', PhD dissertation, Liberty University, Lynchburg, VA. 